\title{
2010 Labour Party Leadership Election
}

\section{Süreyya Yiğit*}

\begin{abstract}
:
Britain is an established parliamentary democracy traditionally dominated by two political parties: Labour and Conservative. General election defeats usually prompt leadership challenges by candidates promising electoral success at the next election. 2010 was no exception with many Labour Members of Parliament offering themselves as the solution to fix the party's electoral problems. Ed Miliband emerged as the victor in the Labour leadership contest, beating his elder brother alongside his other rivals. His success was dependent on his self portrayal as a left-wing candidate who had learned the relevant lessons from the mistakes encountered under Tony Blair's New Labour. His vision of a new generation of political leader embracing long held cherished Labour values was a success. The leadership election demonstrated that internal divisions persisted within the Labour Party despite the election of a new leader.
\end{abstract}

Keywords: $\quad$ Labour Party, British Politics, General Elections, Social Democracy, Leaders

${ }^{*}$ Ph. D., Istanbul Aydin University 
The British general election of 6 May 2010 produced an inconclusive result. The results made it clear that the Conservatives had won the most votes nationwide: $36 \%{ }^{1}$ Furthermore, that they also possessed the largest number of seats in the House of Commons: $305 .^{2}$ They did not, however, have an outright majority in Parliament. The incumbent Labour Party was relegated to second place in terms of most votes received (29\%) and as the second largest party in Parliament with 258 seats. ${ }^{3}$ As for the Liberal Democrats they had once more come third in both votes (23\%) and seats (57). ${ }^{4}$ They received fewer seats than in the previous Parliament despite increasing their percentage of the national vote. ${ }^{5}$

Yet, there was nothing new with such a situation. It was not the first time that the British electorate had spread its preferences and trust in relatively similar proportions to three political parties. British political traditions do not give the party with the largest seats an automatic opportunity to try and form an administration. Until and unless an incumbent Prime Minister can clearly see that another party or a combination of parties can command a majority in the House of Commons s/he is duty-bound to remain in office, whatever other parties may hope for. As in all democracies, the previous government holds onto power until a new government can be formed. The 2010 election in many ways reminded observers of the election of 28 February 1974, when the incumbent Conservative Party lost its majority and returned to the House of Commons as the second largest party; the exact situation the Labour Party faced in $2010 .^{6}$

The Labour Party having lost the general election began debating and voting for who they wanted to lead them into the next election. They were desperate to find the right person who would return them to government. The loss of the elixir of power especially after more than a decade in continuous governance had been particularly difficult to come to grips and digest, which transformed that particular summer into a political heat wave.

Gordon Brown had held out for five days after the May 6 General Election, hoping to remain at No: 10, but finally quit as both Prime Minister and party leader, personally accepting the responsibility for the defeat. ${ }^{7}$ The resignation speech was the starting gun for the leadership race that ended on September 25th. ${ }^{8}$ Several of the candidates had been preparing for this moment for weeks and months, if not for years.

\section{Leadership Candidates}

The party leader was chosen through a vote broken down into three categories, known as an electoral college. Labour Party MPs and MEPs, party members and members of affiliate organizations were all asked to vote individually and the results from the separate categories each made up a third of the final result. ${ }^{9}$

Of the five candidates vying for the leadership position, the one who made the most of preparing over the last few months was the ex-Foreign Minister David Miliband, appointed to that position in June 2007. At the time he was 41 years old, and the third youngest person to hold that portfolio after Lloyd-George at 38 and David Owen at 39 years of age. He was considered to be a successful Environment Minister prior to the promotion to the Foreign Office after becoming an MP in 2001, after working as head of the Downing Street Policy Unit.

With Brown as Prime Minister, British newspapers reported that he was preparing a coup to topple him two years ago in $2008 .{ }^{10}$ In the end he did not act and was later to claim that it was out of loyalty to Brown that he did not challenge him. David Miliband was nominated by 81 MPs, 165 constituency Labour parties, 6 MEPs, 2 trade unions and one socialist society. ${ }^{11} \mathrm{He}$ was by far the most successful fundraiser having raised more than $£ 324,000$ in June and July combined. ${ }^{12}$

When Gordon Brown finally resigned most thought that the Labour leadership contest would be between the two Miliband brothers. David was the favourite in most quarters and his younger brother did hesitate before offering himself as a candidate, thinking that doing so was in the interests of the party. 
Therefore, the younger brother of David, Ed Miliband also participated in the race to become the next Labour Leader. He was popular with workers, having secured important backing from the biggest trade union leaders. The General, Municipal, Boilermakers and Allied Trade Union (GMB) one of the three biggest unions to support the party, had threatened to withdraw funding if he were not to win the contest. ${ }^{13}$ Ed had been competent in the cabinet as the Minister in charge of energy and climate as well as having written the party's losing election manifesto. He was regarded politically as more to the left than his elder brother having joined the Labour Party at the tender age of 17. Prior to becoming an MP in 2005 he had worked for Mr. Brown during his early years as chancellor, focusing on long-term policy development becoming chairman of the Treasury's council of economic advisers. Ed was nominated by 63 MPs, 6 trade unions, 151 constituency Labour parties, 6 MEPs and 3 socialist societies; he was able to raise more than $£ 61,000$ in June and July. ${ }^{14}$

For political observers, the brothers were interesting as both had achieved Cabinet rank, they appealed to the party voters and the electorate at large due to their photogenic qualities and youthful appearance, to analysts because they were interesting due to their policy stances. To academics they are interesting not because of whom they were per se, but due to their father: Ralph Miliband.

Ralph Miliband born to Polish Jewish parents, who had migrated to Belgium, was a respected academic, well known for the books he wrote in the 1960s and 1970s focusing on Parliamentary Socialism, The State in Capitalist Society, as well as, Marxism and Politics. After settling in war-torn Britain in 1940 he had established himself as a recognised influential left-wing intellectual. He was a keen observer, even a member for a few years and contributor of opposing ideas to the Labour Party, meeting regularly with prominent left-wing MP's such as Michael Foot, Tony Benn and Ian Mikardo to discuss what a socialist programme ought to be. He was excruciatingly critical of the party, asserting that it was too conservative in its stance, hence continually punching below its weight against the capitalist system. Neither brother privately or publicly shared their father's view.

Apart from Ralph Miliband's two sons the ex-Minister for schools and children, Ed Balls was also a strong candidate to become leader of the party. Balls became a Cabinet Minister in June 2007, after just two years having entered the House of Commons. His real importance lay in the fact that for a decade he was Gordon Brown's chief economic adviser at the Treasury, closest political confidante, playing a vital role in major policy decisions. Whilst he could not claim to have an influential and recognizable father, he was the only person in British political history to sit in the cabinet with his wife: Yvette Cooper, the ex-Minister for Work and Pensions. Ed Balls was nominated by 33 MPs, 17 constituency Labour parties and one trade union; he was able to raise more than $£ 118,000$ in June and July combined. ${ }^{15}$

The fourth candidate standing for the leadership was Andy Burnham, the ex-Minister for Health. This position, handling one of the biggest-spending departments in government, provided him with valuable experience but he had to endure criticisms focusing on his youthful appearance and lack of wide experience. The Miliband brothers and Ed Balls had not had to answer to such accusations. Before being responsible for the high-budget health job he was the cabinet minister for culture and prior to that, in the important position of chief secretary to the Treasury. Andy Burnham was nominated by 33 MPs, 44 constituency Labour parties, one MEP, no trade union and one socialist society. ${ }^{16} \mathrm{He}$ was able to fundraise more than $£ 22,000$ in June and July combined. ${ }^{17}$

Diane Abbot, Britain's first black woman MP was the most flamboyant candidate in the field. She had been an MP for 23 long years, having witnessed the party's terrible years in the political wilderness for more than a decade. She had never held governmental office during this time, though despite the unpopularity of Labour in May 2010, she was one of only a handful to increase her majority. Diane Abbot was nominated by 33 MPs, 20 constituency Labour parties, no MEPs, two trade unions and one socialist society. ${ }^{18}$ She did not declare any money as a result of fundraising.

When investigating the candidates from the point of view of political stance, Diane Abbot was clearly positioned on the left of the political spectrum with David Miliband on the opposite right. In between and jostling for the left-leaning conscience of the party were Ed Balls and Ed Miliband 
with Andy Burnham, being closest to Diane Abbot. At the initial stage one could not say that a single individual had emerged as the guaranteed winner from the leadership contest. David Miliband the media-friendly, super-fundraiser was the favourite entering the final stage of this particular five-horse political race. Despite the fact that he was nominated by more of his parliamentary colleagues than his brother, he was aware that his colleagues were prone to changing their allegiances. MPs always want to ensure they do not back a horse that stumbles in the final hurdle thereby protecting their careers. This being due to the fact that their votes will be recorded and later on, made public.

The last time the Labour Party held a leadership contest was sixteen years earlier; Tony Blair had won the support of $60 \%$ of MPs/MEPs, $58 \%$ of ordinary party members and $52 \%$ of affiliate organizations. ${ }^{19}$ The votes from each category were divided proportionately and the final result showed Blair had won with $57 \%$ share of the overall vote. ${ }^{20}$

In 2010 it looked highly likely that the son of Ralph Miliband would become the leader of a political party their father loathed. Whichever son would win, it seemed highly probable that he would not do it through getting a majority of the votes outright, but rather through winning other candidates' second preferences.

\section{Leadership Election}

The results after the first round of voting confirmed that Diane Abbott had received overall $7.42 \%$ of the vote coming in fifth. ${ }^{21}$ She received $0.877 \%$ of the votes from MPs and MEPs, $2.447 \%$ of the votes from party members and $4.093 \%$ of the vote from trade unions and affiliated societies. ${ }^{22}$

Andy Burnham had come fourth with $8.68 \%$ of the overall vote. ${ }^{23}$ He received $3.008 \%$ of the votes from MPs and MEPs, $2.849 \%$ of the vote from party members and $2.825 \%$ of the vote from trade unions and affiliated societies. ${ }^{24}$ Ed Balls was third with $11.79 \%$ of the total vote. ${ }^{25}$ He received $5.013 \%$ of the votes from MPs and MEPs, $3.371 \%$ of the vote from party members and $3.411 \%$ of the vote from trade unions and affiliated societies. ${ }^{26}$

Ed Miliband had come in second with $34.33 \%$ of the total vote. ${ }^{27}$ He received $10.526 \%$ of the vote from MPs and MEPs, $9.978 \%$ of the vote from party members and $13.821 \%$ of the vote from trade unions and affiliated societies. ${ }^{28}$ David Miliband led the first round with $37.78 \%$ of the total vote. $^{29} \mathrm{He}$ received $13.910 \%$ of the vote from MPs and MEPs, $14.688 \%$ of the vote from party members and $9.182 \%$ of the vote from trade unions and affiliated societies. ${ }^{30}$ With no candidate getting more than $50 \%$ of the overall vote, Diane Abbott was eliminated as she had come in last and her second preference votes redistributed.

In the second round the results showed that Andy Burnham had come last with $10.41 \%$ of the overall vote. ${ }^{31}$ He received $3.03 \%$ of the vote from MPs and MEPs, 3.298\% of the vote from party members and $4.078 \%$ of the vote from trade unions and affiliated societies. ${ }^{32}$ Ed Balls had come third with $13.3 \%$ of the overall vote. ${ }^{33}$ He received $5.171 \%$ of the vote from MPs and MEPs, $4.224 \%$ of the vote from party members and $3.829 \%$ of the vote from trade unions and affiliated societies. ${ }^{34}$

Ed Miliband was second again in the second round with $37.47 \%$ of the total vote. ${ }^{35} \mathrm{He}$ received $11.111 \%$ of the vote from MPs and MEPs, $11.13 \%$ of the vote from party members and $15.231 \%$ of the vote from trade unions and affiliated societies. ${ }^{36}$ David Miliband continued to lead in the second round as well with $38.89 \%$ of the overall vote. ${ }^{37}$ He received $14.015 \%$ of the vote from MPs and MEPs, $15.076 \%$ from party members and $9.799 \%$ of the vote from trade unions and affiliated societies. ${ }^{38}$ Once more as no candidate received more than $50 \%$ of the overall vote, Andy Burnham was eliminated and his votes redistributed according to preferences.

In the third round, as was expected Ed Balls came last with $16.02 \%$ of the overall vote. ${ }^{39} \mathrm{He}$ received $5.429 \%$ of the vote from MPs and MEPs, $4.823 \%$ of the vote from party members and $5.76 \%$ of the vote from trade unions and affiliated societies. ${ }^{40}$ Ed Miliband once again came second with $41.26 \%$ of the overall vote. ${ }^{41} \mathrm{He}$ received $12.121 \%$ of the vote from MPs and MEPs, $12.424 \%$ of the vote from party members and $16.706 \%$ of the vote from trade unions and affiliated societies. ${ }^{42}$ 
David Miliband was first with $42.72 \%$ of the overall vote. ${ }^{43}$ He received $15.783 \%$ of the vote from MPs and MEPs, $16.076 \%$ of the vote from party members and $10.861 \%$ of the vote from trade unions and affiliated societies. ${ }^{44}$ With no candidate getting more than half of the overall vote, Ed Balls was eliminated and his votes redistributed according to preferences.

It was in the fourth and final round that the results confirmed that David Miliband had come in second with $49.35 \%$ of the total vote. ${ }^{45}$ He received $17.812 \%$ of the vote from MPs and MEPs, $18.135 \%$ of the vote from party members and $13.40 \%$ of the vote from trade unions and affiliated societies. ${ }^{46}$ Ed Miliband came first for the only time in all the four rounds of voting receiving $50.65 \%$ of the overall vote. ${ }^{47}$ He received $15.522 \%$ of the vote from MPs and MEPs, $15.198 \%$ of the vote from party members and $19.934 \%$ of the vote from trade unions and affiliated societies. ${ }^{48}$

Labour Party officials stated that after four rounds of voting Ed Miliband won with 175,519 votes whilst David Miliband received 147,220 votes. ${ }^{49}$ Therefore, having passed the magical fifty per cent barrier, Ed Miliband was declared the winner of the contest and subsequently elected as the leader of the Labour Party.

\section{Ed Miliband's Victory}

In his very short victory speech, perhaps the most important point Ed Miliband made was his desire "to build a new kind of economy that works for people. We will address inequalities and expand opportunity. And we will place values at the heart of our society: values of family, time, work, community and the environment around us". 50

Given the fact that Britain was experiencing painful public expenditure cuts with much tighter belt-tightening on the horizon, the economy was first and foremost on the political agenda. Despite all the measures taken by the Labour government of 1997-2010, inequality had increased in Britain. That was a damning statement for a social democratic party, hence the importance attached to inequality in particular and the economy in general.

Ed Miliband was also correct to pay attention to values. It was the government that he was part of that brought restrictions on civil liberties through measures concerning detention and the introduction of identity cards. The Labour Party had traditionally been a party that had defended and advanced democracy. It had consistently supported parliamentary democracy. ${ }^{51}$

Within that stance there had always been a steadfast defence of civil liberties and the rights of the individual. It would be completely understandable for a social democratic party to accept that it had made mistakes and return to upholding human rights and national values. As is usually the case, the aftermath of results is not the appropriate time to make detailed promises highlighting particular policy stances. Ed Miliband abided with this approach and spoke of three emotions, one observation and one promise.

The hopes of the electorate, quite predictably, were on his mind. The party had lost five million votes only four months earlier; therefore, the new leader had no alternative but to address this disturbing fact. He accepted that the party had to give hope to the nation in a troubled time. With increasing inflation, unemployment and inequality hope was at a premium, which was something a youthful new leader could provide.

The second emotion he addressed concerned dreams. The dream of a united party working together hand in hand, rather than with daggers drawn against each other. The dream of losers gathering around the new leader to offer support, rather than attempting to plan his downfall. The aspirations of the public had to be welcomed and encouraged with a realistic strategy offering them the realisation of their dreams being spelled out.

The third emotion concerned fear. The worry of losing - whether one's job, home or health. These were very real fear. A political fear that would raise its head concerned the electoral reform referendum planned for May 2011. Should the referendum endorse the status quo, the coalition could well come to a halt as the Liberal Democrats considered the benefits of remaining in office with a party diametrically opposed to their core policy. On the other hand should the referendum accept the Alternative Vote (AV), then it would be the turn of the Conservatives to fear the next election, 
whereby the secondary preferences of Lib Dem voters could push Labour ahead. Unfortunately, these were only two of the many fears that were doing the rounds in Britain at that moment.

The observation that Ed Miliband made concerned uncertainty which was something that he personally knew quite well as he himself had been uncertain for four months whether he would win the leadership race or not. There was uncertainty in the air with regard to what kind of a new party would emerge under his leadership. There was uncertainty with regard to how deep the spending cuts would be, how the rise in VAT scheduled for January 2011 would impact the electorate, what would the reaction in Wales be in the spring for the planned referendum offering more political powers to the Welsh. These were tough times calling for tough measures. The new leader was quite fortunate that it was his political rivals, Clegg and Cameron who were associated with school budget cuts and higher taxes.

The one promise that Ed Miliband made was the usual one for a new leader: change. No leader could have defended the status quo: three election victories in a row and then a defeat. If all was well and victory gained, then more of the same could have been a credible offer. After a defeat, there needed to be introspection. Causes had to be recognized. Perhaps, even culprits identified. Where had the party gone wrong? Why had millions leave the party at the ballot box in droves? What were the current needs of the nation? How could the present situation be bettered? These were all queries occupying Labour minds at the time.

Change in a political party is inevitable. Some of the changes can be good. Those who had welcomed Blair in 1994 forecast a generation in power, only for it to come crumbling down after thirteen years. Perhaps it would have been better had Brown become leader earlier? That was not the case, and when he did finally lead the government the external environment and the Blair legacy were too much to come to grips with. Therefore, when contemplating radical change or a break with the past, this needed to be thought out very carefully indeed.

The "New Labour" project won three elections and lost one, therefore, it should be recorded as a historical success. It had to be noted, however, that "New Labour" had been defeated at the polls by the people who mattered, not the party faithful, but the electorate. That was the real reason why Ed Miliband wanted change. Without it he could not win a general election. And if he could not win, then he would lose, there being no in-between.

\section{Previous Labour Leaders}

The unwritten rule was that young men with little experience did not become leaders of the Labour Party. This time the new leader of the Labour Party was young indeed and without much House of Commons experience. Compared to his predecessors he was certainly a newcomer. Gordon Brown had been an MP for 24 years before becoming leader. Tony Blair had been an MP for 11 years, John Smith for 22 years, Neil Kinnock for 13 years, Michael Foot for 35 years, James Callaghan for 31 years, Harold Wilson for 18 years, Hugh Gaitskell for 10 years and Clement Attlee had been a member of the House of Commons for 13 years before becoming leader. Ed Miliband had only been elected an MP in 2005.

It is at the very outset that political leaders' power, influence, authority, charm, ideas, vision and advocacy are at its apex. At times, this chain with its entire links can be strengthened as was the case with Blair for a decade. Afterwards all the links in the chain can begin to disentangle. This can clearly be demonstrated when viewing modern post-war Labour leaders all testifying to this hypothesis.

Attlee was the leader of the party for two full decades, but near the end of his tenure, the party had split between the right wing led by Hugh Gaitskell and the left led by the charismatic orator Aneurin Bevan. Attlee remained as leader in part to ensure his deputy leader Herbert Morrison would not succeed him. Such was the state of the party in 1955: division and rivalry, both ideological and personal.

With Gaitskell as leader, the party split deepened with both wings of the party contemptuous of each other. Gaitskell has always been remembered as a party leader who after having lost an 
important defence policy vote, would 'fight, fight and fight again to save the party we love'. This indicated the depth of the divisions and mutual dislike within the party when he was leader. The party at this stage of its existence was desperately trying to tear itself apart, which the premature death of the leader only froze briefly.

Arguably Labour's most successful election winner, Harold Wilson, inherited the leadership with his left-leaning credentials. He ensured that Labour were the largest party in Parliament in four of the five elections he contested, but even that was not enough to bring calm to the ideological sparring within the party. He kept a tight lid on open criticism and was successful due to providing the party with much sought after power, though citing old age he retired in office. He was replaced by an older James Callaghan, who became leader just like Gordon Brown, whilst in government, therefore, becoming Prime Minister as well. Representing the right wing, but hoping to give guidance to the party, his loss at the next election ensured that his short tenure could not continue.

The next leader was an even older Michael Foot, who positioned and considered himself as the compromise leader, but was firmly from the very left of the party. His leadership witnessed very bitter confrontations within the party, which culminated in several high profile ministers leaving to establish a new political party. That was the historical low point for both the leadership and the party, with the election manifesto of 1983 being dubbed the "longest suicide note in history".

Neil Kinnock was a young left winger who took over after a devastating election loss, trying to extinguish the extremists from the party. After a decade of trials and tribulations, he to a great extent succeeded, but was unable to persuade the electorate that the party was electable. He did notice two potential leaders however, and gave Blair and Brown their first important shadow portfolios.

John Smith took over the leadership next and before he could ask the voters for an opportunity to serve he suffered an untimely death, similar to Gaitskell. It was in his brief stewardship, that the party became more balanced and popular, with both wings accepting his wise council and leadership. Gordon Brown, initially the favourite to succeed his fellow Scotsman, declined in favour of his political ally and Tony Blair, another rising star in the ranks, contested and won the leadership and completely revamped the party.

He changed the long held allegiance and advocacy for public ownership, successfully changing the image of Labour as a high-tax party. This whole process of complete modernisation - he termed "New Labour". Ecstatically popular before, during, and after the 1997 election within the party, he ended his days as a leader who could count on very little support both in cabinet, in the House of Commons or in the constituency parties. He epitomised the spectacular rise, as well as the hard fall.

Taking charge of both government and party, Gordon Brown had an unenviable mountain of debris to climb, left over from a decade of Blair. Unpopular actions, weariness from being in power for so long, he had no effective control over the party, with several of his ministers openly plotting to overthrow him. Having waited in the wings for more than a decade it was a terrible tragedy for the party's most successful and longest serving Chancellor of the Exchequer, to have his leadership of the party cut short. With Brown as leader, the party suffered its worst defeat in terms of percentage of votes cast for it in an election since the suicidal 1983 result.

Ed Miliband needed to read deeply into the history of the Labour Party where he could see young and old, popular and hated, unifying and divisive leaders. Much separated them in terms of policy, global viewpoint, defence preferences, economic stimuli and many other issues, but they were all united as - paraphrasing from Enoch Powell - 'all leaders careers end in failure'. They all had the same beginning, being crowned leader and they all suffered the same fate: they were able to push the party in a particular direction but then got run over by the very same party machine. Even Wilson, the effective winner of four elections, did not have the heart or the stamina to continue as party leader and preferred to leave on his own terms, gradually distancing himself into the political background.

Ed Miliband was probably aware that of all the post-war Labour leaders apart from Wilson, only two others had actually won general elections: Attlee and Blair. One must recall, however, that Attlee had last won sixty years earlier. All the rest, whilst being able to lead the party, had not been 
able to lead the nation. Some had been intellectual powerhouses for both the left and the right wing of the party. Others had tried to appease both factions, though all had to struggle to create consensus and gain momentum. Miliband had to take steps to ensure he would be in the small minority of nationally popular Labour Party leaders, rather than those concentrating on increasing their power within the party, irrespective of the electorate.

\section{Leadership Challenges}

Now that Ed Miliband was leader, he faced multiple tests, something he was used to given he was the Minister in charge of energy and climate change for a year and a half. The first and most important challenge that faced him was his very own party.

The Labour Party after experiencing its most successful decade and a half in its existence had reverted to being in opposition. The party faithful had gotten used to being in power, of governing. Now they were out of it, most were suffering from withdrawal symptoms. Some were grateful for actually not being the government as the current circumstances called for tough measures, which would have to be taken by the Coalition This provided a golden opportunity to formulate new ideas or develop older ones.

It was the battle for ideas that had to mark the Miliband leadership and the issue was critical when recalling that his social democratic party had lost five million votes in an election where the electorate was told by all major parties that the next five years would be very tough on all working people. Rather than capitalize on this situation, the party had lost the trust and confidence of the electorate. Certainly people did not vote only bearing the future in mind but also the past. This had been a referendum on the Labour government and the people decided they did not want more of the same, but change. That was precisely the theme Miliband had chosen from the very outset for the party.

It was only by changing some of its ideas, especially the economic and social ones that the party could change its fortune and the outcome of the previous election. Which ideas needed to be changed? The New Labour agenda of better management, improved administration needed to be reappraised. Labour needed to reiterate itself as a party which defended the defenceless, that helped the poor and the downtrodden, that spoke up for those that had no voice.

It needed to stand for the values that made it so popular in the past: the belief in social justice, fairness, individual liberty, opportunity and solidarity. If Miliband could advocate and advance those ideas and values then the Labour Party could return as the major force in British politics that it was for a decade and a half. The party needed to make it clear that economic injustices could not be morally acceptable and would not be when in government. Miliband had to demonstrate which issues made Labour different than Conservative or Liberal Democrat.

The new leader was not, as the Conservative Party Chair said "the choice of his MPs, wasn't the choice of Labour Party members but was put in to power by union votes. I'm afraid this looks like a great leap backwards for the Labour Party". ${ }^{52}$ That was factually correct and could be damming. It was true that Ed Miliband only got more than half the votes in just five Constituency Labour Parties there being 650 constituencies in the UK - and was elected due to the electoral college system that gave trade unions and affiliated societies an equal one third say in electing the leader alongside MPs and MEPs as well as ordinary party members.

This meant that some trade unionists who were not members of the Labour Party could and did elect the leader. Their vote counted as much as a party member. This was particularly difficult to defend for Ed Miliband as he had only won with $50.65 \%$ of the total votes in the electoral college, highly dependent on the large unions mobilising their members to vote for him. ${ }^{53}$

Unluckily for him, he held the mantle of being the first leader in the party's history to be elected without the majority support of his party members. As if that were not enough, he did not even have the majority support of his fellow labour parliamentarians in the House of Commons. That was the reason why so much had been asserted about how independent he could be from the unions that he owed so much to. 
A more democratic selection should not give equal weight to non-party members and all party members' votes should have equal weight. Andy Burnham, a defeated contender rhetorically but rightfully asked that "I don't see why my vote as an MP is worth 600 times the vote of an ordinary party member". ${ }^{54}$ The clear implication being that could not be permitted in a social democratic party as it is anti-democratic. Miliband, in order to establish his democratic credentials had to move the party towards a one-member-one-vote electoral system for all major positions. Quite naturally, it is very difficult for a leader to advocate democratic elections and democracy when it does not exist in their own party.

The new leader had to look inward to his party and investigate and appraise it. What were the strengths and the weaknesses that were demonstrated in the last few years, perhaps from the time since the changeover from Blair to Brown, perhaps from 2003 onwards. Obviously foreign policy was a primary candidate for weakness, namely the decision to invade Iraq. This action was unpopular in the country at large, as well as within the party and the parliamentary labour party. Soul searching needed to be carried out, concentrating on what it really meant to be Labour. That had to focus on values. Either the party stood for certain values or it fell by the wayside. Labour was far from that prospect as it performed quite well in the 2010 election, considering the position it was in. Thirteen years of responsibility was a very heavy load indeed.

In conclusion, ultimately Labour Party members were agonizingly aware during the leadership campaign that the electorate had indeed abandoned them due to mistrust. The electorate clearly stated that they did not wish for more of the same. Part of that was related to the leader, but some part was also attributed to the cabinet - to which Ed Miliband belonged. Therefore, collectively the Labour Party was punished and it had to recuperate collectively. That would necessitate leading from the front which was why Ed Miliband was given that role. As in so many cases, the hope placed in a new Labour leader was not to be realised.

\section{Notes}

${ }^{1}$ Fisher, J. and Wlezien, C. The UK General Election of 2010: Explaining the Outcome. Taylor \& Francis, 2013.

${ }^{2}$ Seldon, A. and Finn, M. The Coalition Effect, Cambridge University Press, 2015.

${ }^{3}$ Collin, R.O. and Martin, P.L. An Introduction to World Politics: Conflict and Consensus on a Small Planet.

Rowman \& Littlefield Publishers, 2012.

${ }^{4}$ Denver, D. and Garnett, M. British General Elections Since 1964: Diversity, Dealignment, and Disillusion. Oxford University Press, 2014.

${ }^{5}$ Kavanagh, Dennis and Cowley, Philip. The British General Election of 2010. Palgrave MacMillan, 2010.

${ }^{6}$ Denver, D. and Garnett, M. British General Elections Since 1964: Diversity, Dealignment, and Disillusion. Oxford University Press, 2014.

${ }^{7}$ Adonis, A. 5 Days in May: The Coalition and Beyond. Biteback Publishing, 2013.

${ }^{8}$ Jay, A. Lend Me Your Ears: Oxford Dictionary of Political Quotations. Oxford University Press, 2010.

${ }^{9}$ Quinn, T. Electing and Ejecting Party Leaders in Britain. Palgrave Macmillan, 2012.

${ }^{10}$ Bisikay, A. Why Managers Can't Lead and Leaders Can't Manage. Lulu Enterprises Incorporated, 2009.

${ }^{11}$ Labour Party (2010b), 'Candidate booklet' (London: Labour Party)

${ }^{12}$ David Miliband well ahead on cash for Labour leadership fight, The Guardian, 23 July 2010.

${ }^{13}$ Union threatens to withdraw funding over Labour leadership battle, The Daily Telegraph, 28 August 2010.

${ }_{15}^{14}$ Labour Party (2010b), 'Candidate booklet' (London: Labour Party)

${ }^{15}$ ibid.

16 ibid.

17 ibid.

18 ibid.

19 A Heppell, T. Choosing the Labour Leader: Labour Party Leadership Elections from Wilson to Brown. I.B.Tauris, 2010. 


\section{Süreyya Yiğit}

${ }^{20}$ ibid.

${ }^{21}$ Labour Party (2010a), 'The Labour party internal elections 2010' (Manchester: Labour Party)

22 ibid.

${ }^{23}$ ibid.

24 ibid.

25 ibid.

${ }^{26}$ ibid.

${ }^{27}$ ibid.

${ }^{28}$ ibid.

${ }^{29}$ ibid.

${ }^{30}$ ibid.

31 ibid.

32 ibid.

${ }^{33}$ ibid.

${ }^{34}$ ibid.

35 ibid.

36 ibid.

${ }^{37}$ ibid.

${ }^{38}$ ibid.

${ }^{39}$ ibid.

40 ibid.

${ }^{41}$ ibid.

42 ibid.

${ }^{43}$ ibid.

${ }^{44}$ ibid.

45 ibid.

${ }^{46}$ ibid.

${ }^{47}$ ibid.

48 ibid.

${ }^{49}$ ibid.

${ }^{50}$ Miliband, Ed. "The New Generation Speech", 28 September 2010, in www.labour.org.uk/ed-miliband---anew-generation (retrieved on 13.09.2015)

${ }^{51}$ Incurring the hostility of Ed's father, Ralph Miliband

${ }^{52}$ Ed Miliband wins Labour leadership, Financial Times, 25 September 2010.

${ }^{53}$ Pemberton, H. R., \& Wickham-Jones, M. (2013). Brothers all? The Operation of the Electoral College in the 2010 Labour Leadership Contest. Parliamentary Affairs, 66(4), 708-731.

${ }^{54}$ Labour leadership contest 'neck and neck', 24 September 2010, in http://www.bbc.co.uk/news/mobile/ukpolitics-11405784 (retrieved on 15.09.2015) 